\section{Mortality in free range rescued wild animals of Shivalik Hills of Himachal Pradesh, India}

\author{
Vijay Kumar, 1 Vipin Kumar,2 Anshu Raj3 \\ 1Monkey Sterilization Centre-Gopalpur; \\ 2Monkey Sterilization Centre-Hamirpur, \\ Nature Park Gopalpur, Hamirpur; \\ 3Veteinary Hospital, Deol, Baijnath, Distt \\ Kangra, H.P. India
}

\section{Abstract}

The present study was conducted on 143 free range wild animals of 12 different species rescued from different locations in Shivalik Hills since Jan 2004 to June 2011. Mortality was reported in $79.02 \%$ (113) of rescued wild animals. Mortality in Herbivores, Carnivores, Pheasants and Omnivores was $84.74 \%$ (50), $79.06 \%$ (34) $72.72 \%$ (24) and $62.50 \%$ (05) respectively. Post mortem was conducted at field level to determine causes of mortality in all the 113 died wild animals. Necropsy findings revealed musculoskeletal injuries 68.14\% (77), more specifically fractures $37.16 \%$ (42) and fatal trauma $30.97 \%$ (35) as most common cause of mortality in all the animals. On the other hand Cardiovascular and haemorrhagic shock constituted $11.50 \%$ (13) while septicemia were noted in $8.84 \%$ (10) of all the recorded causes of mortality in rescued animals. Mortality with other causes noticed in $11.50 \%$ cases is attributable to diagnosed causes including froathy bloat, tympany, intussusceptions, senility with associated lesions and unknown causes like infectious diseases or toxicosis without a clear symptomatology. The highest mortality was found in male herbivores $28.31 \%$ (32) followed by female carnivores $16.81 \%$ (19) and male pheasants $13.27 \%$ (15). Only $39.82 \%$ (45) mortality was observed in adult animals compared to juveniles $51.32 \%$ (58). Mortality in winter season $52.21 \%$ (59) was higher than summer $33.62 \%$ (38) and rainy season $14.15 \%$ (16).

\section{Introduction}

Uncontrollable human population growth leading to the industrialization and urbanization is rapidly replacing natural habitat, local vegetation and decreasing free space for wild animals day by day. ${ }^{1}$ This inter-specific competition for resources between human and wild animals has forced a decline in population of free range wild animals. The growing livestock population has also created a competition for feed and fodder by overgrazing surrounding the forest area causing a local declining population of wild herbivores. ${ }^{2}$ The seasonal variation also causes a change in their diet and prey so these wild animals move from one place to other in search of their prey which exposes these to different adverse conditions like road accidents and human - wild life conflict leading to more mortality of these free range wild animals. ${ }^{3}$ The death analysis of free range wild populations is very difficult to perform because most deaths go unobserved. Moreover, it is very difficult to know the exact cause of the mortality in free range wild animals from natural or unnatural factors. The unnatural factors includes mainly two predisposing factors $\mathrm{viz}$. Infectious and noninfectious diseases. ${ }^{4,5}$ Some non infectious agents can have a great effect on the mortality of the wild animals. 6 The interrelationship between wild animals, human beings and domestic animals has become important now a days as there was found some diseases involvement of wild animals in transmission of certain interspecies as well as intra-species diseases. For effective control and prevention of mortality in free range wild animals, it is important to be knowledgeable of various conditions affecting the free range wild animals. The present study is the first work on the mortality of the free range wild animals in Shivalik Hills in India. The objective of present study was to determine the mortality and causes of mortality among the free range wild animals, rescued from different locations of the Shivalik Hills of Himachal Pradesh in India.

\section{Materials and Method}

\section{Study area}

Himachal Pradesh is situated to Jammu and Kashmir in the North and Haryana in the South-West, Uttranchal in South-East and Punjab in the West of the state. Himachal Pradesh is a hilly region with an altitude ranging from 350 meters to 7000 meters above sea level and latitude $30^{\circ} 22^{\prime} 40^{\prime \prime}$ North to $33^{\circ} 12^{\prime} 40^{\prime \prime}$ North and longitudes $75^{\circ} 45^{\prime}$ 55" East to $79^{\circ} 04^{\prime}$ 20" East.Himachal Pradesh is broadly divided into three zones on the basis of altitude of the state Shivalik Hills or outer Himalayas, Mid Himalayas and Great Himalayas. Shivalik Hills altitude ranges from 1050 feet to 4500 feet above sea level. Shivalik Hills mainly covers the areas of Distt. kangra, Una, Hamirpur, Bilaspur and lower parts of Solan and Mandi districts of the state. Shivalik hill area constitute $30 \%$ of total geographical area and $55 \%$ of total cultivated area of the state.

\section{Data for study}

The present study is based on post mortem
Correspondence: Vijay Kumar, Monkey Sterilization Centre-Dhauladhar, Vill - Laka, P.O Sarkaghat, Distt-Mandi, H.P. 175024 India.

Tel. +91.945.913.3330.

E-mail: drvijay0220@gmail.com

Key words: mortality, free range, rescued wild animals, Shivalik Hills, Himachal Pradesh.

Acknowledgement: the authors are thankful to D.F.0 wild Life - Hamirpur Sh. Satish Gupta, ACF Smt Sangeeta as well as all the Zoo workers, Gopalpur, for their assistance throughout the work.

Contributions: VijK, data collection, VipK, AR, compilation of data.

Conflict of interest: the authors report no conflicts of interest.

Received for publication: 29 0ctober 2011. Accepted for publication: 12 January 2012.

This work is licensed under a Creative Commons Attribution NonCommercial 3.0 License (CC BYNC 3.0).

CC Copyright V. Kumar et al., 2012

Licensee PAGEPress srl, Italy

Veterinary Science Development 2012; 2:e2 doi:10.4081/vsd.2012.e2

findings of rescued wild animals died during March 2004 to June 2011. Gross necropsies were conducted at field level to determine causes of mortality in all the 12 different species of free range wild animals, rescued from different locations of Shivalik Hills, Himachal Pradesh. The animals were broadly divided into four groups viz. Herbivores, Carnivores, Omnivores and Pheasants. Data pertaining to history, age, sex, species, date and cause of death were examined. The age of animals was arbitrarily divided into infant, juvenile and adult. Incidence of mortality in different animal in relation to season was also examined.

\section{Results}

A total of 143 free range wild animals (59 Herbivores, 43 Carnivores, 8 Omnivores and 33 Pheasants) representing 12 different species were rescued from different locations in Shivalik hills during March 2004 to June 2011. The records pertaining to mortality were examined and results presented.

Mortality was reported in $79.02 \%$ (113) of the 143 rescued wild animals. Among died animals, $84.74 \%$ (50 of 59) were herbivores, $79.06 \%$ (34 of 43 ) were carnivores, $72.72 \%$ (24 of 33 ) were pheasants and $62.50 \%$ (5 of 8 ) were omnivores. (Table 1). 
Table 1. Causes of mortality in rescued wild animal of Shivalik Hills, H.P., India (2004-2011).

\begin{tabular}{|c|c|c|c|c|c|c|c|c|c|}
\hline Sr. & Common name & Species & & & & & ise of death & & \\
\hline & & & & & $\begin{array}{l}\text { Musculoskel } \\
\text { Fracture }\end{array}$ & $\begin{array}{l}\text { Injuries } \\
\text { Trauma }\end{array}$ & Septicemia & Shock & Other \\
\hline $\begin{array}{l}1 \\
1.1 \\
1.2 \\
1.3 \\
1.4\end{array}$ & $\begin{array}{l}\text { Herbivores } \\
\text { Sambar } \\
\text { Barking deer } \\
\text { Goral } \\
\text { Nil gai }\end{array}$ & $\begin{array}{c}\text { (Cervus unicolor) } \\
\text { (Muntiacus muntjak) } \\
\text { (Nemorhaedus goral) } \\
\text { (Boselaphus tregocamelus) }\end{array}$ & $\begin{array}{l}59 \\
29 \\
09 \\
13 \\
08\end{array}$ & $\begin{array}{c}50(84.74) \\
25(86.20) \\
08(88.88) \\
11(84.61) \\
06(75)\end{array}$ & $\begin{array}{c}20(40) \\
9(36) \\
4(50) \\
5(45.45) \\
2(33.33)\end{array}$ & $\begin{array}{c}17(34) \\
9(36) \\
2(25) \\
3(27.27) \\
3(50)\end{array}$ & $\begin{array}{c}5(10) \\
4(16) \\
1(12.50) \\
0(0) \\
0(0)\end{array}$ & $\begin{array}{c}4(8) \\
1(4) \\
1(12.50) \\
2(18.18) \\
0(0)\end{array}$ & $\begin{array}{c}4(8) \\
2(8) \\
0(0) \\
1(9.09) \\
1(16.66)\end{array}$ \\
\hline $\begin{array}{l}2 \\
2.1 \\
2.2 \\
\end{array}$ & $\begin{array}{l}\text { Carnivores } \\
\text { Leopard } \\
\text { Leopard cat }\end{array}$ & $\begin{array}{c}\text { (Panthera pardus) } \\
\text { (Felis (prionailurus) bengalensis) }\end{array}$ & $\begin{array}{l}43 \\
31 \\
12\end{array}$ & $\begin{array}{l}34(79.06) \\
26(83.87) \\
08(66.66)\end{array}$ & $\begin{array}{l}14(41.17) \\
13(50) \\
1(12.50)\end{array}$ & & & $\begin{array}{l}4(11.76) \\
3(11.53) \\
1(12.50)\end{array}$ & $\begin{array}{l}3(8.82) \\
2(7.69) \\
1(12.50)\end{array}$ \\
\hline $\begin{array}{l}3 \\
3.1 \\
3.2\end{array}$ & $\begin{array}{l}\text { Omnivores } \\
\text { Black bear } \\
\text { Wild boar }\end{array}$ & $\begin{array}{l}\text { (Selenaretos thibetanus) } \\
\text { (Sus scrofa) }\end{array}$ & $\begin{array}{l}08 \\
03 \\
05\end{array}$ & $\begin{array}{c}05(62.50) \\
01(33.33) \\
04(80)\end{array}$ & $\begin{array}{c}2(40) \\
0(0) \\
2(50)\end{array}$ & $\begin{array}{c}1(20) \\
1(100) \\
0(0)\end{array}$ & $\begin{array}{l}0(0) \\
0(0) \\
0(0)\end{array}$ & $\begin{array}{l}1(20) \\
0(0) \\
1(25)\end{array}$ & $\begin{array}{l}1(20) \\
0(0) \\
1(25)\end{array}$ \\
\hline $\begin{array}{l}4 \\
4.1 \\
4.2 \\
4.3 \\
4.4 \\
\end{array}$ & $\begin{array}{c}\text { Pheasants } \\
\text { Himalyan monal } \\
\text { Peacock } \\
\text { Cheer phesant } \\
\text { Snow partidge }\end{array}$ & $\begin{array}{c}\text { (Lophophorus impejanus) } \\
\text { (Pavo cristatus) } \\
\text { (Catreus wallichii) } \\
\text { (Lerwa lerwa) }\end{array}$ & $\begin{array}{l}33 \\
08 \\
03 \\
14 \\
08\end{array}$ & $\begin{array}{c}24(72.72) \\
04(50) \\
02(66.66) \\
12(85.71) \\
06(75) \\
\end{array}$ & $\begin{array}{c}6(25) \\
1(25) \\
0(0) \\
4(33.33) \\
1(16.66) \\
\end{array}$ & $\begin{array}{c}8(33.33) \\
1(25) \\
1(50) \\
4(33.33) \\
2(33.33)\end{array}$ & $\begin{array}{l}1(4.16) \\
1(25) \\
0(0) \\
0(0) \\
0(0)\end{array}$ & $\begin{array}{c}4(16.66) \\
0(0) \\
0(0) \\
1(8.33) \\
3(50)\end{array}$ & $\begin{array}{c}5(20.83) \\
1(25) \\
1(50) \\
3(25) \\
0(0) \\
\end{array}$ \\
\hline & Total & & 143 & $113(79.02)$ & $42(37.16)$ & $35(30.97)$ & $10(8.84)$ & 13(11.50) & 13(11.50) \\
\hline
\end{tabular}

Post mortems were conducted at field level to determine causes of mortality in all the 113 died wild animals and results presented. Necropsy findings revealed musculoskeletal injuries $68.14 \%(77)$, more specifically fractures $37.16 \%$ (42) and fatal traumatic injuries $30.97 \%$ (35) as most common cause of mortality in all the animals. Mortality due to Septicemic conditions was observed in $8.84 \%$ (10) of died animals. In present study, Septicemic verminous gastroenteritis was recorded in three Sambars as a cause of death.

Septicemic conditions involving respiratory system was observed in three carnivores as cause of mortality. One sambar had hemopericardium with bread and butter appearance, adhesions of pericardium and pleura.

Shock constituted $11.50 \% 13$ of all the recorded causes of mortality in rescued animals. Cardiovascular shock associated with post capture myopathy and stress leading to sudden or deferred was observed in two leopards. Haemorrhagic shock due to severe injuries and/or respiratory failure due to drowning were also observed in some animals as a cause of death.

On the other hand mortality with other known and unknown causes was noticed in $11.50 \%$ (13) cases of which froathy bloat and tympanitis were responsible for deaths in one Sambar and Nilgai, intussusceptions was observed in one Goral and death due to senility with associated lesions was seen in some rescued Cheer pheasants. Mortality with unknown causes in some cases is very likely attributable to infectious diseases or toxicosis without a clear symptomatology.

Incidence of mortality in different groups of wild animals in relation to age and sex (Table 2) showed overall highest mortality in juveniles

Table 2. Incidence of mortality in relation to sex and age group.

\begin{tabular}{ccccccc}
$\begin{array}{l}\text { Sr. } \\
\text { No. }\end{array}$ & $\begin{array}{c}\text { Kind of } \\
\text { animal }\end{array}$ & Sex & $\begin{array}{c}\text { Total } \\
\text { died }\end{array}$ & $\begin{array}{c}\text { Age group } \\
\text { Infant (\%) }\end{array}$ & Juvenile (\%) & Adult (\%) \\
1 & Herbivores & Male & 32 & $04(12.50)$ & $13(40.62)$ & $15(46.87)$ \\
& & Female & 18 & $01(5.55)$ & $12(66.66)$ & $05(27.77)$ \\
2 & Carnivores & Male & 15 & $0(0)$ & $07(46.66)$ & $08(53.33)$ \\
& & Female & 19 & $05(26.31)$ & $10(52.63)$ & $04(21.05)$ \\
\hline 3 & Omnivores & Male & 01 & $0(0)$ & $01(100)$ & $0(0)$ \\
& & Female & 04 & $0(0)$ & $03(75)$ & $01(25)$ \\
4 & Pheasants & Male & 15 & $0(0)$ & $08(53.33)$ & $07(46.66)$ \\
& & Female & 09 & $0(0)$ & $04(44.44)$ & $05(55.55)$ \\
\hline & & & 113 & $10(8.84)$ & $58(51.32)$ & $45(39.82)$ \\
\hline
\end{tabular}

$51.32 \%(58)$ followed by adults $39.82 \%$ (45) and season (Table 3 ).

Table 3. Incidence of mortality in relation to season.

\begin{tabular}{cccccc}
$\begin{array}{l}\text { Sr. } \\
\text { No. }\end{array}$ & $\begin{array}{c}\text { Kind of } \\
\text { animal }\end{array}$ & $\begin{array}{c}\text { Total } \\
\text { died }\end{array}$ & $\begin{array}{c}\text { Season } \\
\text { Summer (\%) } \\
\text { (Narch-June) }\end{array}$ & $\begin{array}{c}\text { Rainy (\%) } \\
\text { (July-Sept) }\end{array}$ & $\begin{array}{c}\text { Winter (\%) } \\
\text { (Oct-Feb) }\end{array}$ \\
1 & Herbivores & 50 & $18(36)$ & $09(18)$ & $23(46)$ \\
2 & Carnivores & 34 & $07(20.58)$ & $07(20.58)$ & $20(58.82)$ \\
\hline 3 & Omnivores & 05 & $02(40)$ & $0(0)$ & $03(60)$ \\
4 & Pheasants & 24 & $11(45.83)$ & $0(0)$ & $13(54.16)$ \\
\hline & Total & 113 & $38(33.62)$ & $16(14.15)$ & $59(52.21)$ \\
\hline
\end{tabular}

infants $8.84 \%$ (10) of which $55.75 \%$ (63) were males and $44.24 \%$ (50) females. The highest mortality was found in male herbivores $28.31 \%$ (32) followed by female carnivores $16.81 \%$ (19) and male pheasants $13.27 \%$ (15).

Incidence of mortality in different groups of wild animals in relation to season was also determined. Highest mortality in all animals was reported in winter $52.21 \%$ (59) followed by summer $33.62 \%$ (38) and rainy $14.15 \%$ (16)

\section{Discussion}

The data regarding the mortality in free range wild animals in India is sparse, because of very less scientific work in the field of wild life biology. The knowledge regarding the mortality of free range wild animals is very important in prevention and control of the diseases 
as well as mortality in free range wild animals. The prevalence of many disease in wild animals remains unknown because of shy or frightened behavior of the wild animals. ${ }^{7}$

In present study the records pertaining to mortality in respect of 12 different species of free range wild animals, rescued from different locations of Shivalik Hills of Himachal Pradesh in India were examined.

Mortality was reported in $79.02 \%$ (113) of the 143 rescued wild animals. Among died animals, $84.74 \%$ (50 of 59 ) were herbivores, $79.06 \%$ (34 of 43 ) were carnivores, $72.72 \%$ (24 of 33 ) were pheasants and $62.50 \%$ (5 of 8 ) were omnivores.

In the present study musculoskeletal injuries $68.14 \%$ (77) were found as major cause of mortality in rescued animals. These injuries were associated with vehicular trauma, inter and intra specific aggression, wire body grippers and foot traps by poachers sometimes slippery terrains were found as a causation of these incidences. Fracture of femur, dislocation of vertebral column, injuries of thorax and abdomen and severe multiple wounds and complication of injuries were the most inflicting causes noticed in all animals. Acharjyo and Rao have reported $18.59 \%$ deaths in captive wild ruminants due to traumatic injuries. ${ }^{8}$ The workers attributed the traumatic injuries to capture operations, inter and intra species fighting. Deaths due to musculoskeletal injuries in the present study support the view of the earlier workers.

Mortality due to Septicemic conditions was observed in $8.84 \%$ of died animals. Dhoot and Upadhye (2001) reported verminous gastroenteritis as cause of mortality in NilGai. ${ }^{9}$ Verminous gastroenteritis in wild ruminants seems to be important as these species are confined to same habitat and chances of food contamination with faecal matter are always high.

In the present study, shock constituted $11.50 \%$ of all the recorded causes of mortality in rescued animals. Cardiovascular shock associated with post capture myopathy and stress leading to sudden or deferred death in rescued wild animals. Haemorrhagic shock due to severe injuries and/or respiratory failure due to drowning were also observed in some animals. Some workers were of opinion that stress and shock due to environmental fluctuations might be responsible for mortalities in animals especially the young ones.

Mortality with other causes noticed in $11.50 \%$ cases is attributable to known causes including froathy bloat, tympany, intussusceptions, senility with associated lesions and unknown causes like infectious diseases or toxicosis without a clear symptomatology. In the present study intussusceptions and senility with associated lesions were the other causes of mortality in some animals.

In present study the incidence of mortality in different groups of wild animals in relation to age and sex showed higher mortality in juveniles than adults and infants. Mortality in males was higher than females.

Incidence of mortality in different groups of wild animals in relation to season was also determined. Highest mortality in winters can be attributed to cold stress and migrations of animals to lower areas because of heavy snowfall in the higher hills. As a result animals become more prone to vehicular accidents and traumatic injuries.

There is need of interdisciplinary collaborated approach and research in the field of wild life disease management, so that the disease transmission between humans, wild animals and domestic animals can be assessed accurately. ${ }^{10}$ There is need for more scientific studies focusing on monitoring of wild animal diseases and mortality. There are several bases related to carcass recovery, handling of carcass and analysis of carcass to know the cause specific mortality. 11 There is also need of more scientific studies on the causation of mortality of the free range wild animals so that the endangered species living in free range can be conserved.

\section{References}

1. Donald LB, Kelly AD. Morbidity and mortality of urban wildlife in the midwestern United States, 2004; Proceedings 4th International Urban Wildlife Symposium. Available from: http://cals.arizona.edu/ pubs/adjunct/snr0704/

2. Mishra C, Allen P, McCarthy T, et al. The role of incentive programs in conserving the Snow Leopard. Conservation Biology 2003;17:1512-20.

3. Patterson BD, Kasiki SM, Selempo E, Kays RW. Livestock predation by lions (Panthera leo) and other carnivores on ranches neighboring Tsavo National Park, Kenya. Biological Conservation 2004;119:507-16.

4. Sinclair AR. The African buffalo: a study of resource limitation of populations. Chicago: University of Chicago Press; 1977.

5. Tompkins DM, Begon M. Parasites can regulate wildlife populations. Parasitol Today 1999;15:311-3.

6. Borge k, Hanko E, Krunajevic T, et al. On tularemia in the varying hare (lepus timidus L). Nordisk veterinamedicin 1969; 21;95-104

7. Munson L, Cook R. Monitoring, investigation, and surveillance of diseases in captive wildlife. J Zoo Wildl Med 1993;24:28190.

8. Acharjyo LN, Rao AT. Mortality pattern in some Indian captive wild ruminants. Indian J Anim Sci 1987;57:430-5.

9. Dhoot VM, Upadhye SV. Causes of mortality in captive ruminants of Maharajbagh zoo, Nagpur. Zoos' Print Journal 2001;16: 642 .

10. Martin C, Pastoret PP, Brochier B, et al. A survey of the transmission of infectious diseases/infections between wild and domestic ungulates in Europe. Vet Res 2011;42:70.

11. Damien OJ, Dennis MH, Michael DS, et al. Estimating cause-specific mortality rates using recovered carcasses. J Wildl Dis 2009;45:122-7. 